\title{
Disegno e geometria: un itinerario creativo per la progettazione di textures e patterns
}

\author{
Giulia Pettoello
}

Abstract

Protagonista della presente ricerca è la trasformazione della forma. Si studiano le molteplici modalità grafiche rispetto alle quali è possibile tessere, trasformare e modificare le linee di un disegno, partendo dal riconoscimento delle figure geometriche che sottendono ad un particolare oggetto, non necessariamente di design ma anche, anzi maggiormente, di uso comune. Argomenti centrali sono quindi il disegno, la geometria, la comunicazione e la multimedialità. Obiettivo è la rappresentazione e la comunicazione di oggetti attraverso tecniche grafiche integrate, tradizionali e digitali. In particolare viene trattata la tematica della progettazione creativa, a partire dalle figure geometriche individuate nella forma dell'oggetto, di texture e patterns. II disegnare quindi viene inteso come strumento per tracciare e tessere forme e geometrie e quindi nuovi significati ancora inespressi. Disegno quindi inteso come strumento per connettere e per generare molteplici ed originali interpretazioni della realtà, in un momento storico in cui l'aspetto esteriore, quindi la capacità di comunicare, ha grande influenza sulla riuscita, a livello commerciale, di un prodotto. Per essere efficace, 'la pelle' dell'oggetto e quindi la sua texture deve rispondere sia ad un elevato livello di qualità grafica ma soprattutto basarsi su un'idea di progetto significativa. II disegno è lo strumento principe capace di gestire ogni fase del processo creativo, dall'ideazione fino alla rappresentazione cromatica del prodotto finale. II disegno inteso quindi come strumento di analisi, di lettura, di studio e di fonte creativa.

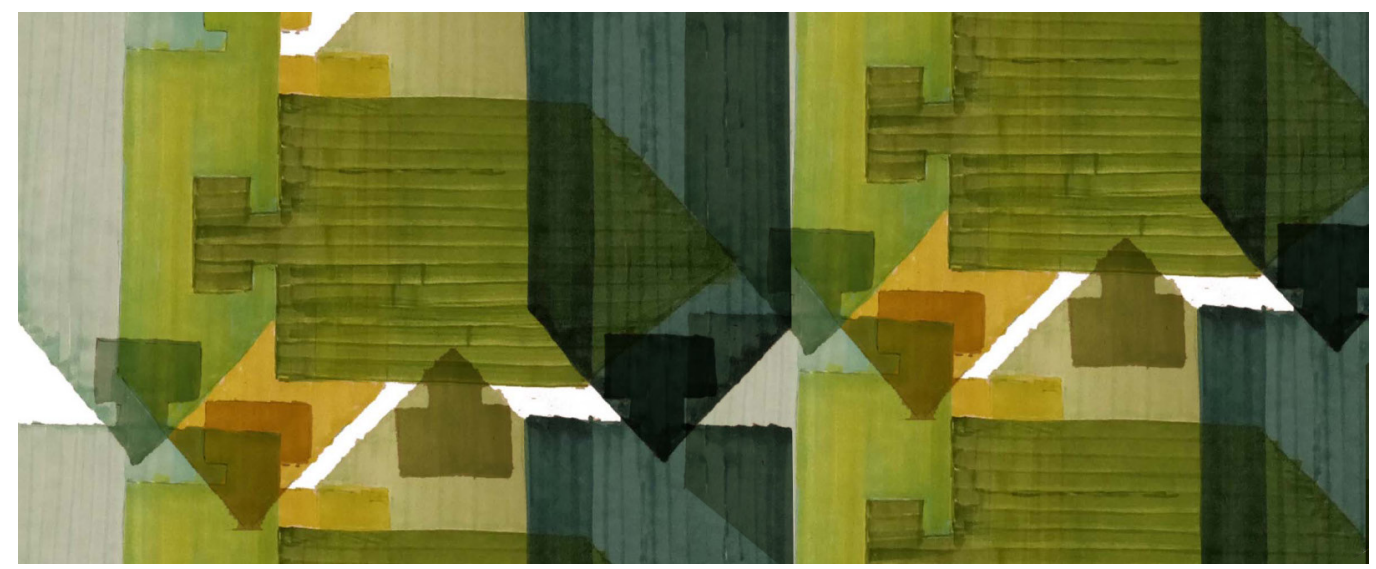




\section{Introduzione}

"Una texture è definita come la qualità visibile e tattile della superficie di un oggetto, che sia liscio, rugoso, morbido, o duro, ed è essenzialmente un effetto visivo che aggiunge ricchezza e dimensione a una qualunque composizione. II termine texture deriva dal latino textura, rete, tessitura. Un pattern, invece è un'immagine formata dalla combinazione di forme organiche o geometriche, e tecnicamente, un motivo o un disegno che si ripete, secondo una simmetria e un ordine. I pattern possono essere semplici o complessi, ma a differenza delle texture, essi appaiono molto più strutturati" [I].

La presente ricerca, work in progress, prevede la realizzazione di texture 'ragionate' partendo dallo studio approfondito di diversi tipi di oggetti di uso comune per i quali si intende progettare e realizzare la caratterizzazione della superficie. In particolare i casi studio qui presentati a titolo esemplificativo riguardano bottiglie di profumo esistenti in commercio, dalle molteplici forme, dalle più semplici alle più complesse (figg. I-3). La texture ed in generale i motivi decorativi non sono dettati dal caso ma derivano da un processo creativo risultato dall'analisi grafica delle principali geometrie individuate nell'oggetto stesso e dalla loro scomposizione. La "pelle" dell'oggetto, quindi, non costituisce un mero valore estetico ma ricopre un valore comunicativo, l'oggetto è quindi fonte principale d'ispirazione per il progettista. Si susseguono diverse fasi di lettura, scomposizione e riassemblaggio per giungere a quello che è il progetto della texture finale. Molto significativo è quanto espresso da Poincaré: "creatività è unire elementi preesistenti con connessioni nuove" [Poincaré 1929]. Nel corso del presente lavoro la 'rappresentazione' viene quindi intesa come operazione creativa che 'smonta' e 'riassembla' sul foglio l'oggetto per far emergere nuove caratteristiche, nuovi significati e quindi nuove idee. II disegno ricopre un ruolo fondamentale in diverse fasi del processo, inizialmente è uno strumento per comprendere, analizzare e studiare
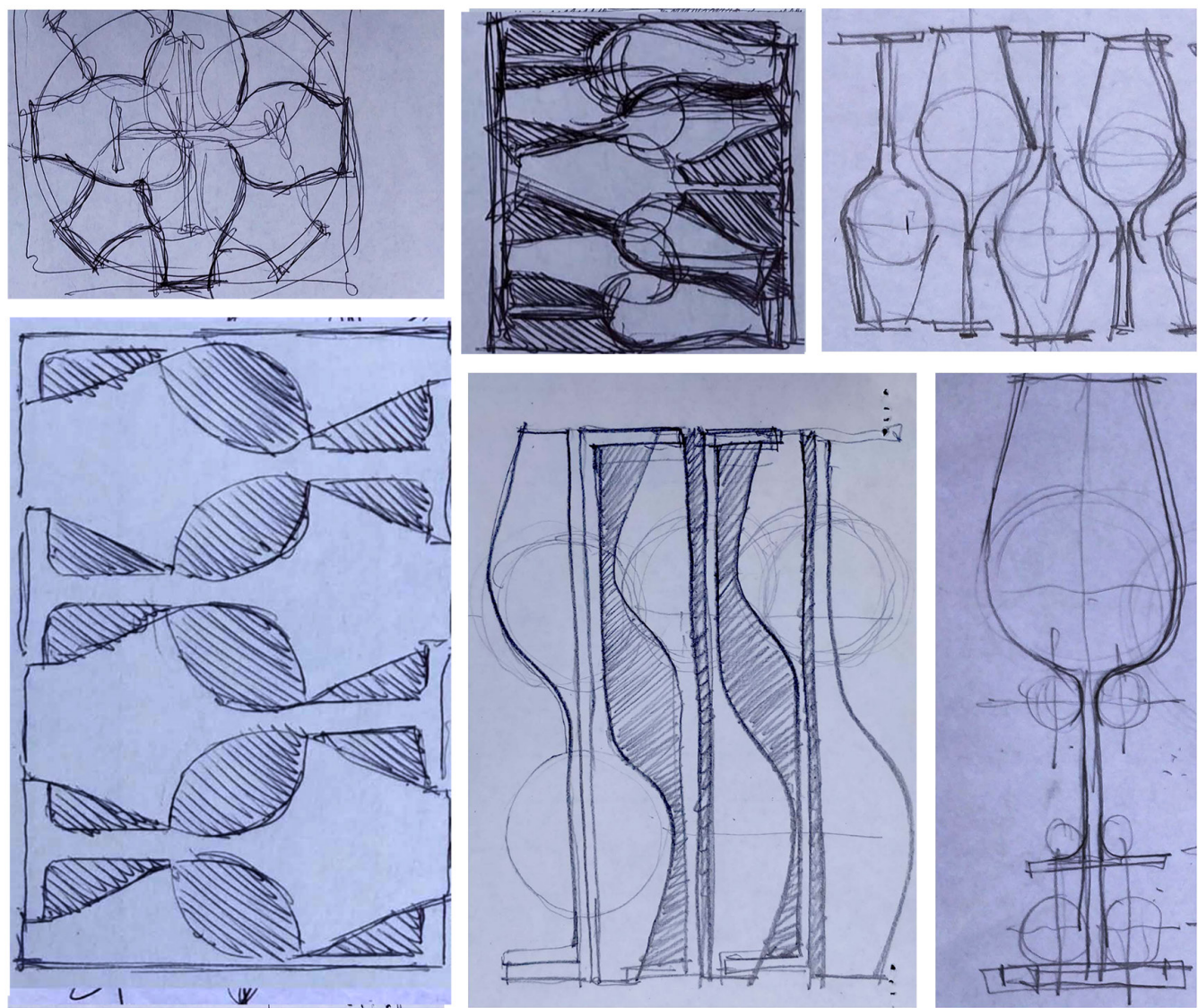
l'oggetto, in un secondo momento è essenziale per la fase creativa e progettuale in cui diverse ipotesi vengono analizzate e confrontate, infine il disegno è la modalità attraverso la quale l'idea prende forma. Fonte d'ispirazione e confronto nel corso della presente ricerca è stata l'opera di Bruno Munari. Munari "considerato uno dei massimi protagonisti dell'arte, del design e della grafica del $20^{\circ}$ secolo, ha mantenuto inalterata la sua estrosa creatività a sostegno dell'indagine costruttiva della forma attraverso sperimentazioni visive e tattili e, insieme, la sua grande capacità di comunicarla attraverso parole, oggetti, giocattoli. Inizialmente vicino al futurismo, se ne allontanò poi gradualmente dedicando la sua ricerca all'approfondimento di forme e colori e all'autonomia estetica degli oggetti' [2].

\section{Riferimenti e stato dell'arte}

La ricerca parte dall'interpretazione del movimento De Stijl per poi apportare una lettura ed un'applicazione personale delle tematiche analizzate. "Nieuwe Beeldende, Neoplasticismo, conosciuto anche come De Stijl (che in olandese significa 'Lo stile') è un movimento artistico nato in Olanda nel 1917. II termine neoplasticismo compare per la prima volta nell'ottobre del 1917 con la pubblicazione del primo numero della rivista De Stijl fondata da Theo Van Doesburg. Questo termine viene utilizzato da Piet Mondrian eTheo van Doesburg nella redazione del Manifesto De Stijl per descrivere la nuova forma d'arte: astratta, essenziale e geometrica" [3]. La ricerca parte dai criteri propri del De Stijl in quanto si fonda su una matrice geometrica di base. La sperimentazione, portata avanti nel corso del presente lavoro, però si evolve in realizzazioni dove si da libero sfogo all'immaginazione e dove le regole alla base delle diverse composizioni variano costantemente dando origine a risultati grafici anche molto eterogenei tra loro. "De Stijl raccoglie l'eredità di molti mo-

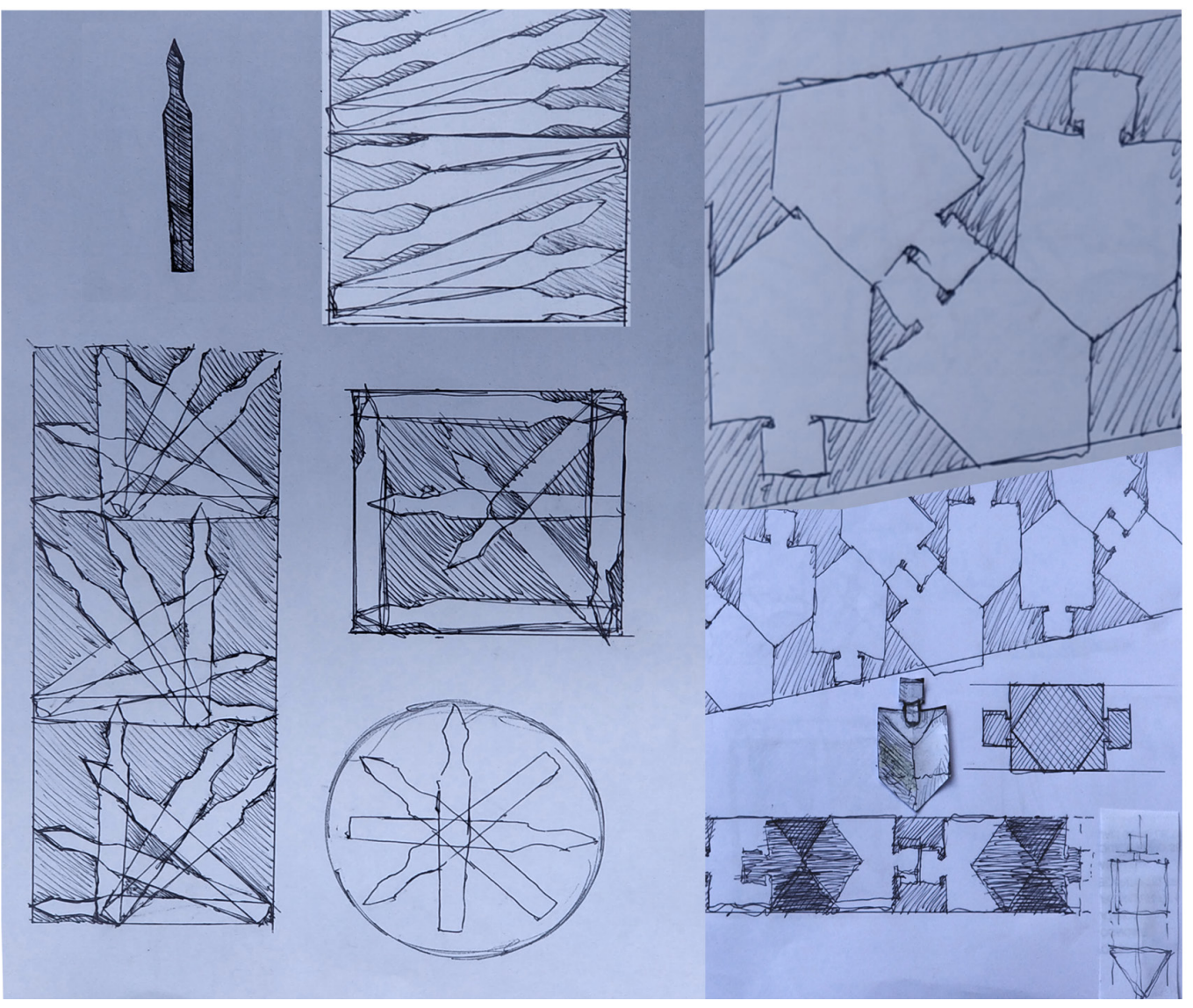


Fig. 3. Schizzi e analisi di oggetti di uso comune (elaborazione grafic dell'autore).

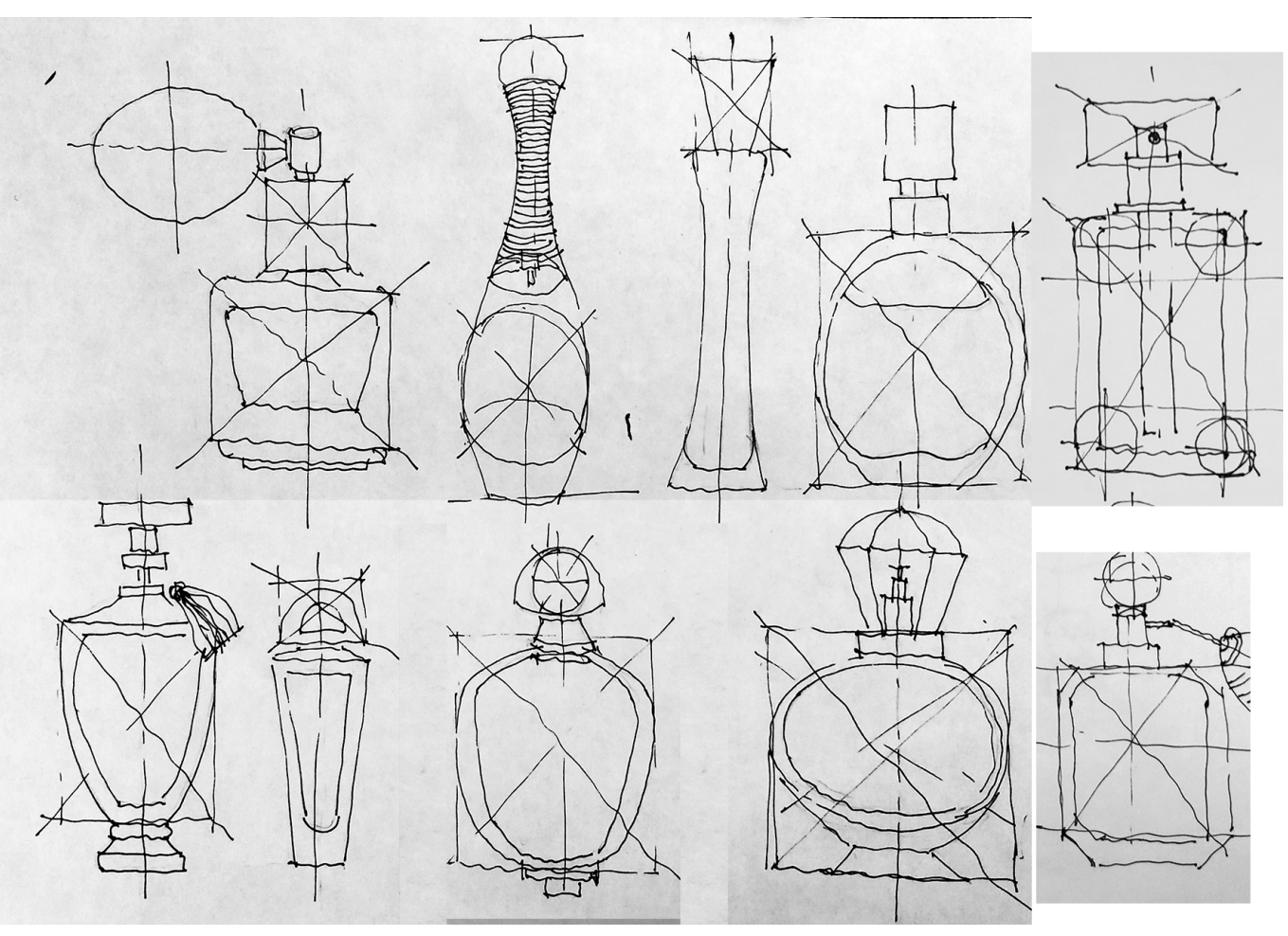

Fig. 4. Disegni di studio Rappresentazione

positivo-negativo. Tecnica: tradizionale e digitale

(elaborazione grafica dell'autore).
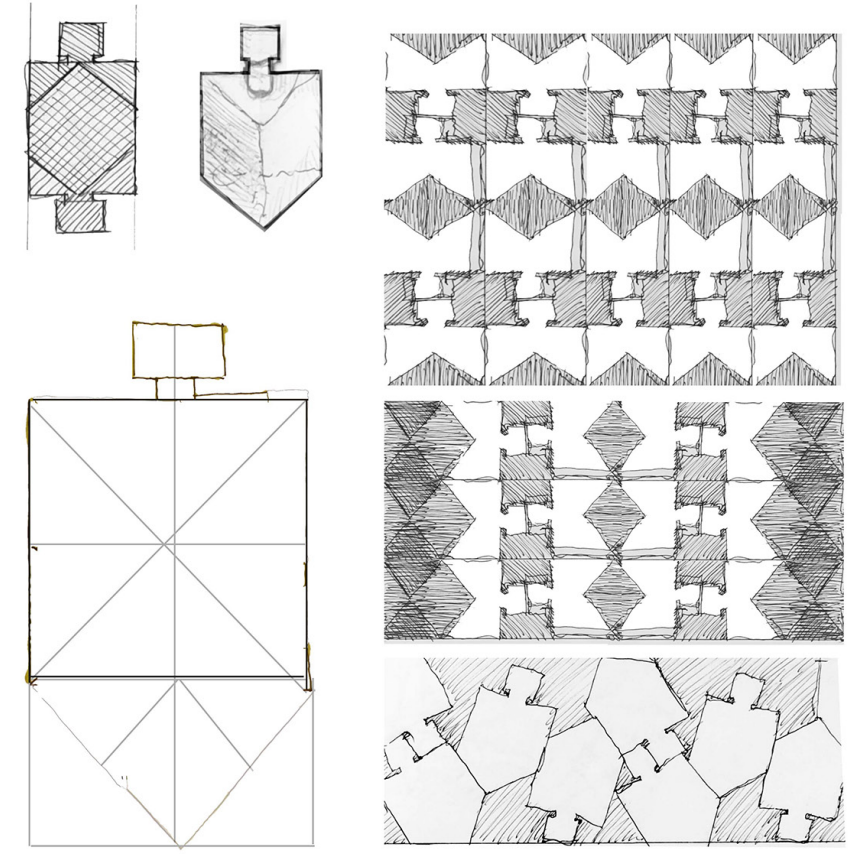
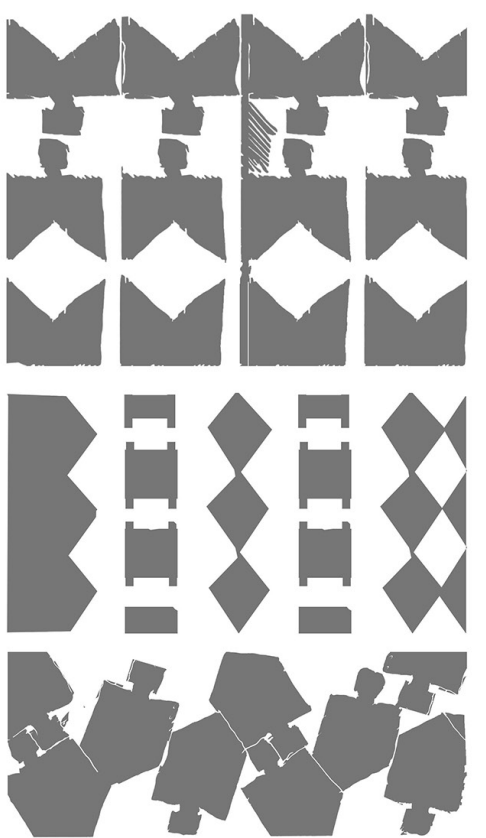
vimenti avanguardisti, porta alle estreme conseguenze la ricerca dell'essenza geometrica della forma inaugurata da Cezanne, l'eliminazione del punto prospettico che da lui hanno derivato i cubisti, la scomposizione della forma complessa in parti elementari attuata dal Cubismo analitico, l'autonomia espressiva del colore di matrice fauve, giungendo inevitabilmente alla eliminazione di ogni contenuto realistico e figurativo, sostituito da forme pure autoreferenziali" [4]. In particolare, le caratteristiche filtrate e reinterpretate dal De Stijl hanno permesso di raggiungere una sintesi grafica essenziale rinunciando all'elemento meramente decorativo.

Oltre al De Stijl ad essere preso come riferimento è anche il movimento del cubismo. Tra le varie opere considerante si riportano di seguito solo le principali: La Chitarra (Pablo Picasso 1923) ed il papier collé, Violino e pipa (Georges Braques 19/3). Nella presente ricerca gli oggetti studiati infatti non vengono mai considerati solamente rispetto al loro prospetto principale ma vengono ruotati, scomposti e rimontati in modo da 'potersi appropriare' dalla loro essenza e generare nuove interpretazioni grafiche. La presente ricerca quindi parte da tali concetti per adattarli ad oggetti di uso comune dandone una lettura diversa ed analizzandone le illimitate potenzialità grafiche ancora inespresse.

Essenziale è stato anche lo studio del lavoro dell'architetto e designer Ettore Sottsass (1917-2007) il quale non si fermava mai ad un unico significato della forma ma ricercava sempre nuove interpretazioni. Particolarmente significative sono le sue sperimentazioni con vetro e cristallo realizzate per la vetreria Vistosi ma anche le opere nate dalla creatività dei Memphis (collettivo italiano di design e di architettura fondato da Sottsass, attivo tra il 198 I ed il 1987). Tra tutte le opere di questo poliedrico artista si vuole porre l'accento sulla libreria Carlton che diventa elemento simbolo dell'intera produzione del gruppo Menphis.

In sintesi quindi gli apporti originali della presente ricerca riguardano in particolare la metodologia proposta volta a creare nuovi significati grafici degli oggetti analizzati. Non ci si limita quindi soltanto alla scomposizione dell'oggetto ma la sua stessa geometria diventa fonte di ispirazione per nuove forme di rappresentazione sintetizzate in texture e pattern.
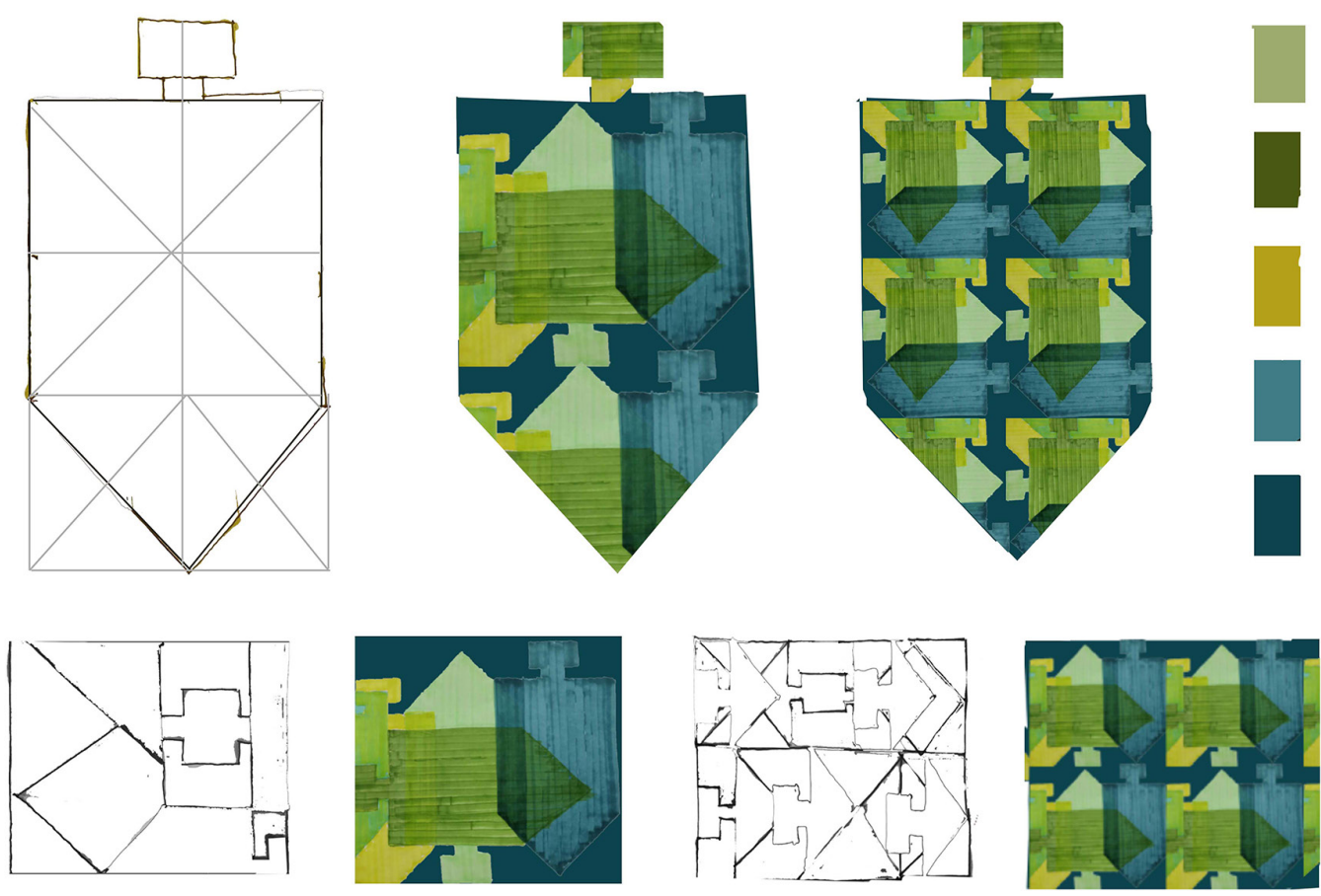


\section{Fasi del processo creativo}

II presente studio, ancora in via di sperimentazione, si struttura come analisi di oggetti esistenti, di uso comune, per costruire un percorso progettuale capace di reinterpretare e rileggere in chiave nuova l'oggetto stesso. Inizialmente lo studio dell'oggetto avviene attraverso schizzi a mano libera in bianco e nero, e solo in un secondo momento, dopo averne rilevato e misurato attentamente le caratteristiche metriche e geometriche, l'oggetto viene rappresentato attraverso i rigorosi metodi della rappresentazione. Dopo questa prima fase di avvicinamento critico all'oggetto si passa ad una sorta di "scomposizione creativa" dell'oggetto, realizzando una sagoma sintetica dell'oggetto analizzato che mantenga, come unico vincolo progettuale, sempre la riconoscibilità del soggetto studiato. Tale sagoma, o ritaglio, viene utilizzato come modulo base in grado di generare texture e pattern derivati proprio dalla giustapposizione, sovrapposizione e incastro della silhouette di base (fig. 4).

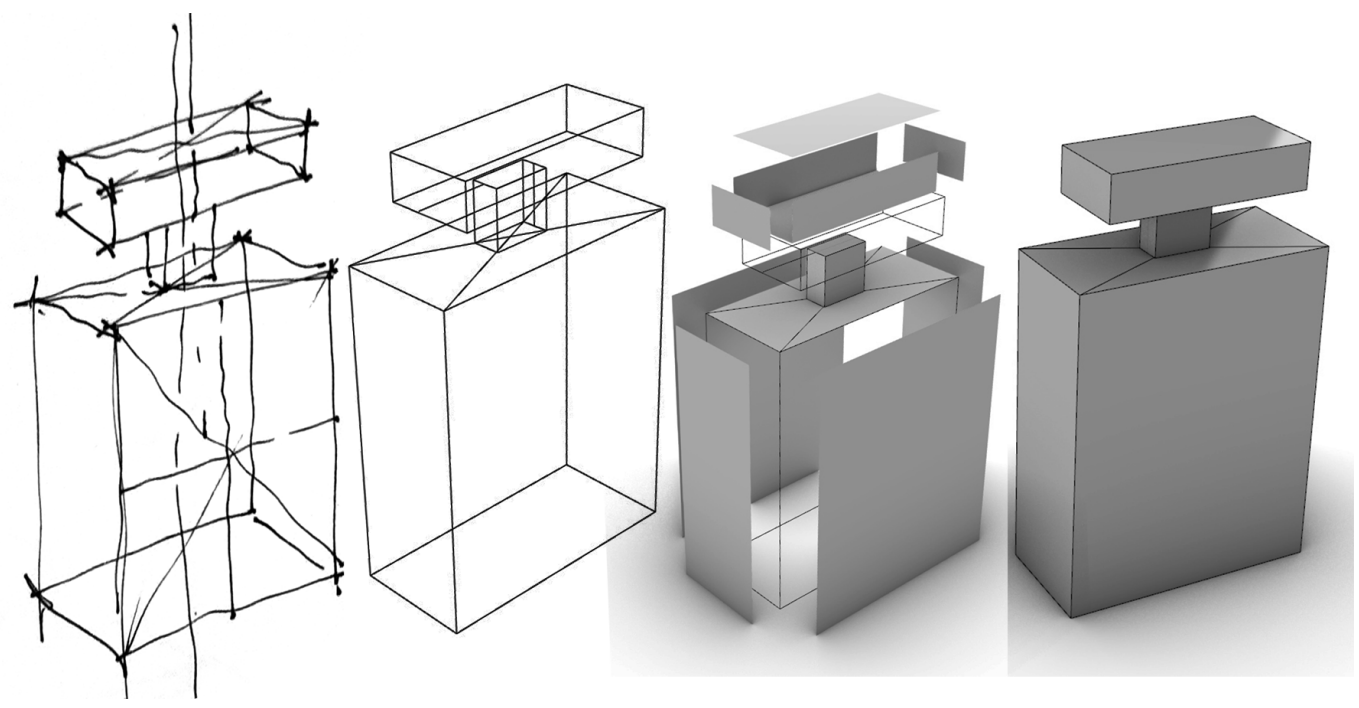

In particolare, per quanto riguarda l'aspetto più prettamente geometrico, tra le principali procedure sperimentate si sintetizzano di seguito le più significative: specchiature rispetto ad un asse di simmetria perpendicolare o inclinato in relazione al paino di base di riferimento; rotazioni rispetto ad una asse centrale o traslato e passante per un punto scelto della figura stessa e proiezioni della sagoma dell'oggetto disposto genericamente nello spazio rispetto agli assi $x, y$,z. L'introduzione dell'aspetto cromatico avviene in maniera, per così dire, tradizionale utilizzando le tecniche dell'acquarello ed il pantone (fig. 5). Dopo questa prima fase di studio, essenzialmente con tecniche tradizionali, si è passati alla realizzazione di un modello digitale tridimensionale dell'oggetto, attraverso l'utilizzo del software Rhinoceros, sul quale, successivamente, sono state applicate le texture realizzate in precedenza (fig. 6). Come è noto l'applicazione della texture al modello 3D è eseguibile secondo diverse modalità più o meno automatizzate a seconda delle caratteristiche della texture di base. In caso di elementi ripetitivi è possibile eseguire un unwrap dell'oggetto direttamente all'interno del software e procedere con l'elaborazione in digitale dell'oggetto finale (fig. 7). Nel caso in cui però si tratti di una texture caratterizzata da un disegno più complesso dove risulta necessaria la progettazione della continuità tra le facce dell'oggetto è anche possibile procedere realizzando lo sviluppo della superficie manualmente per poi procedere con l'applicazione della texture all'interno del software (fig. 8). Grande valore assume la possibilità di continuare ad elaborare il proprio prodotto realizzato con tecniche tradizionali, in ambito digitale (fig. 9). Molto interessante risulta ad esempio la moltiplicazio- 
ne del motivo di base realizzato precedentemente con tecniche tradizionali. All'interno del software Rhino, andando ad agire sulle UV mapping è stato possibile stabilire il fattore di ripetizione più idoneo. Una volta studiato l'accostamento tra le facce e studiata la connessione tra loro è stato infatti sufficiente introdurre un fattore moltiplicativo per realizzare texture con disegni ripetuti più volte giungendo a creazione di 'mosaici' ed incastri molto articolati. Interessante è questo passaggio dove prima era il progettista a dettare le proprie regole, attraverso svariate sperimentazioni grafiche e cromatiche, adesso è il software che, rispetto al materiale prodotto elabora e crea nuovi possibili output a volte anche inattesi perché risultato di un procedimento dinamico e flessibile tra progettista e strumento informatico (fig. 10).

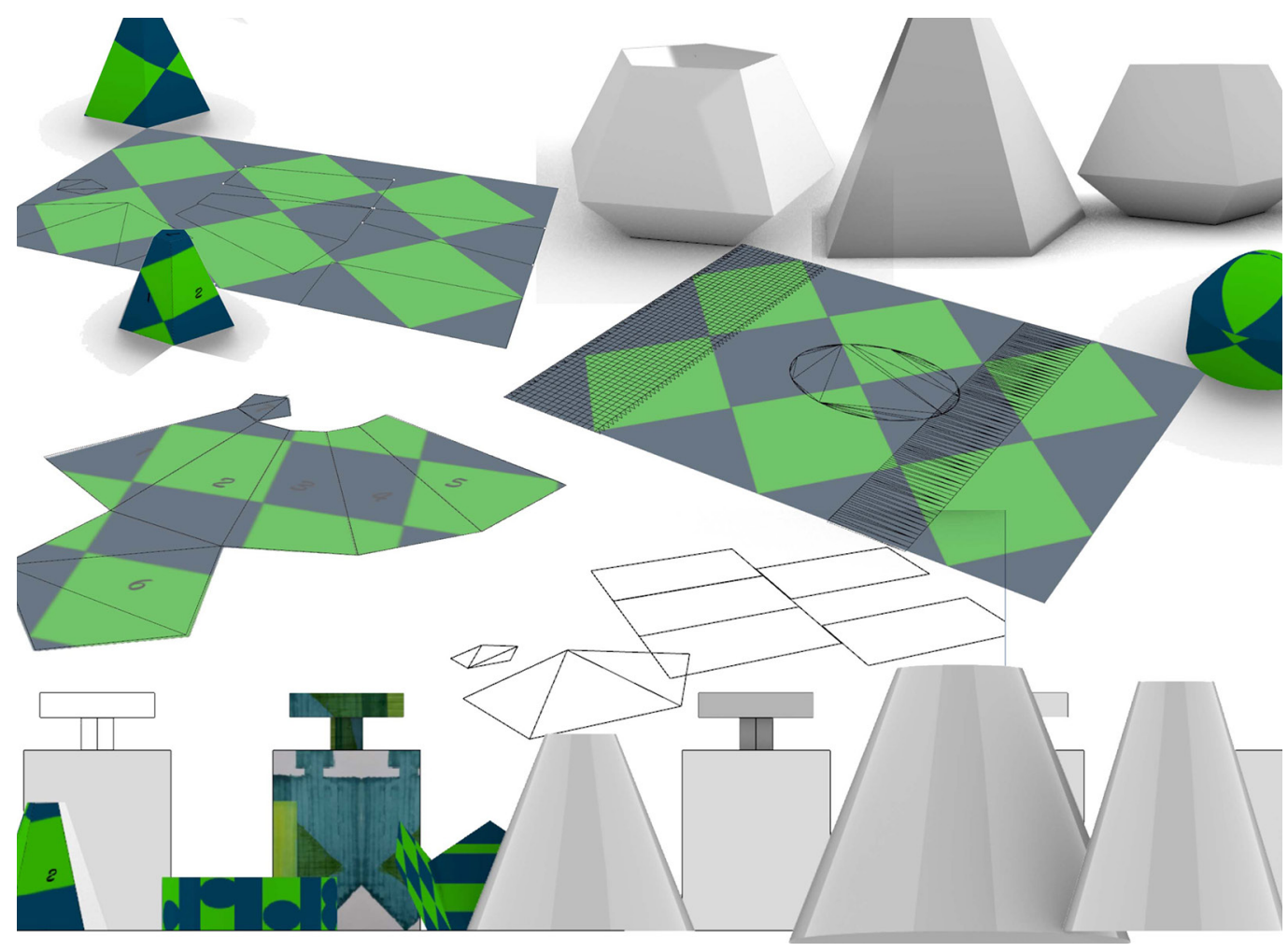

\section{Struttura geometrica}

Come detto in precedenza i motivi generatori delle texture vengono dedotti dalla attenta analisi, comprensione e isolamento delle principali figure geometriche che sottendono, inviluppano e caratterizzano l'oggetto studiato. II flusso progettuale, ideativo, delle texture è dunque fortemente influenzato dall'oggetto di uso comune che sarà a sua volta 'rivestito' da questa nuova caratterizzazione superficiale. L'idea, quindi, insiste sulla circostanza di creare un circolo virtuoso che, a partire dallo studio dell'oggetto, dalla sua scomposizione al riassemblaggio delle geometrie, porti ad una caratterizzazione ad hoc del trattamento superficiale dell'oggetto intimamente connesso con la sua stessa forma. Naturalmente le prime operazioni di scomposizione geometrica partono dalla lettura grafica dell'oggetto, rappresentato in doppia proiezione ortogonale, utilizzando prevalentemente la seconda proiezione (prospetti e sezioni) per individuare assi di simmetria, rette diagonali, ma anche altri elementi geometricamente determinanti come le linee di flesso, o le linee curve. Determinati questi elementi di controllo si individuano le vere e proprie figure geome- 

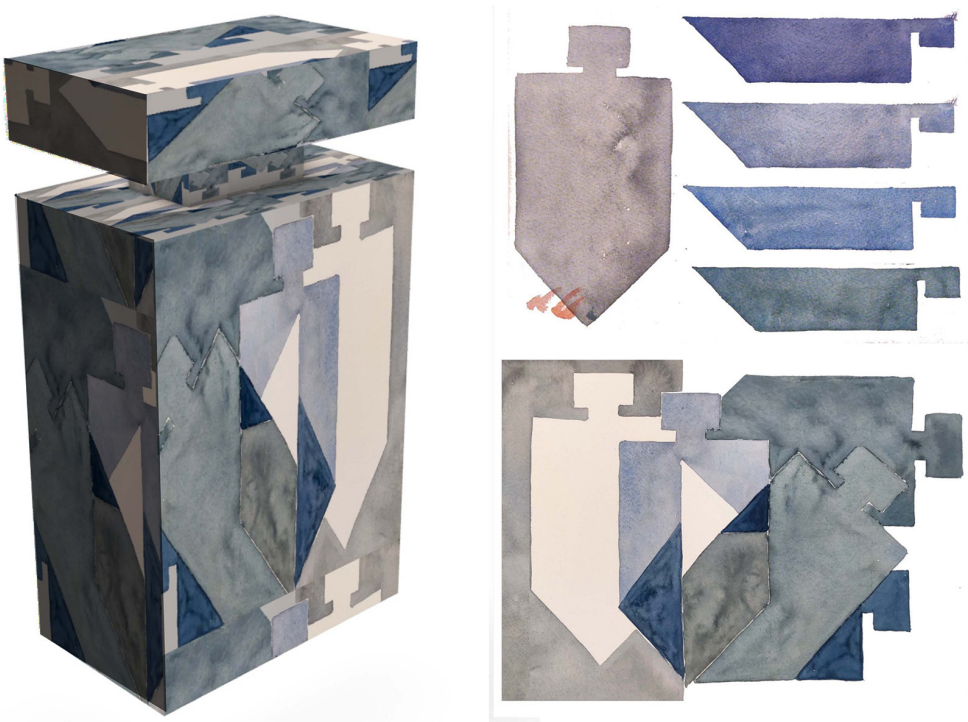

Fig. 9. Sviluppo di una
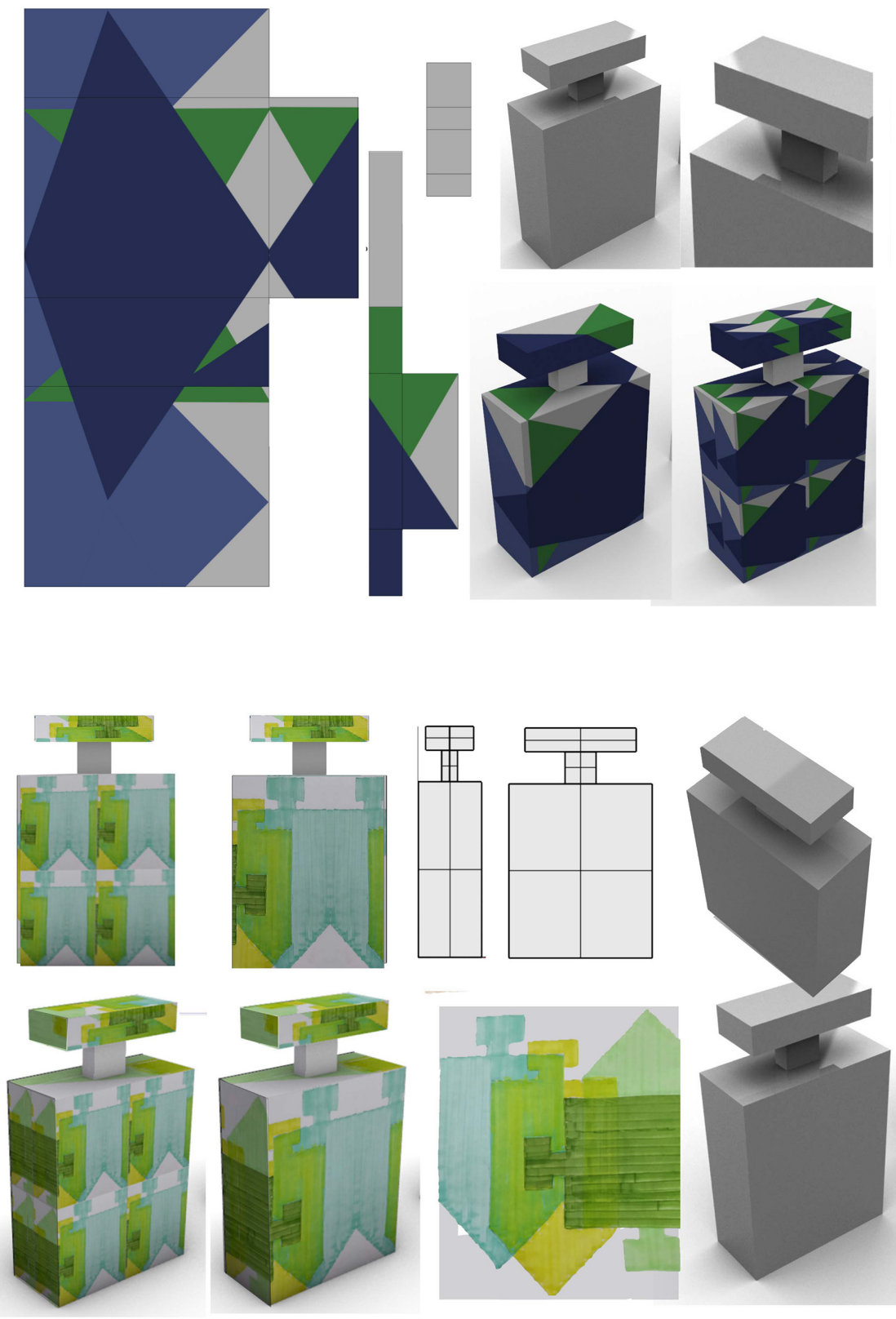
triche elementari che compongono l'oggetto, o parti di esso, quali quadrati, rettangoli e circonferenze. Estraendo le figure geometriche dall'oggetto si è determinato l'elemento generatore, che, attraverso semplici operazioni di ribaltamento, ripetizione, specchiatura, riduzione ed ingrandimento dà vita alla nuova texture. La texture può, naturalmente, essere generata anche per sottrazione ed addizione dei vari elementi, come pure da operazioni di contrasto nero-bianco, o ripetizioni seriali, lungo un percorso rettilineo o curvilineo. L'iter progettuale così ideato non risulta confinato all'interno delle geometrie elementari estratte dall'oggetto, al contrario sfruttando questa idea guida si apre ad infinite possibili soluzioni, che variano in base all'elemento geometrico individuato e alle infinite possibili combinazioni.

Fig. I I. Texture: contaminazione tra tecniche tradizionali e tecniche digitali (elaborazione grafica dell'autore).
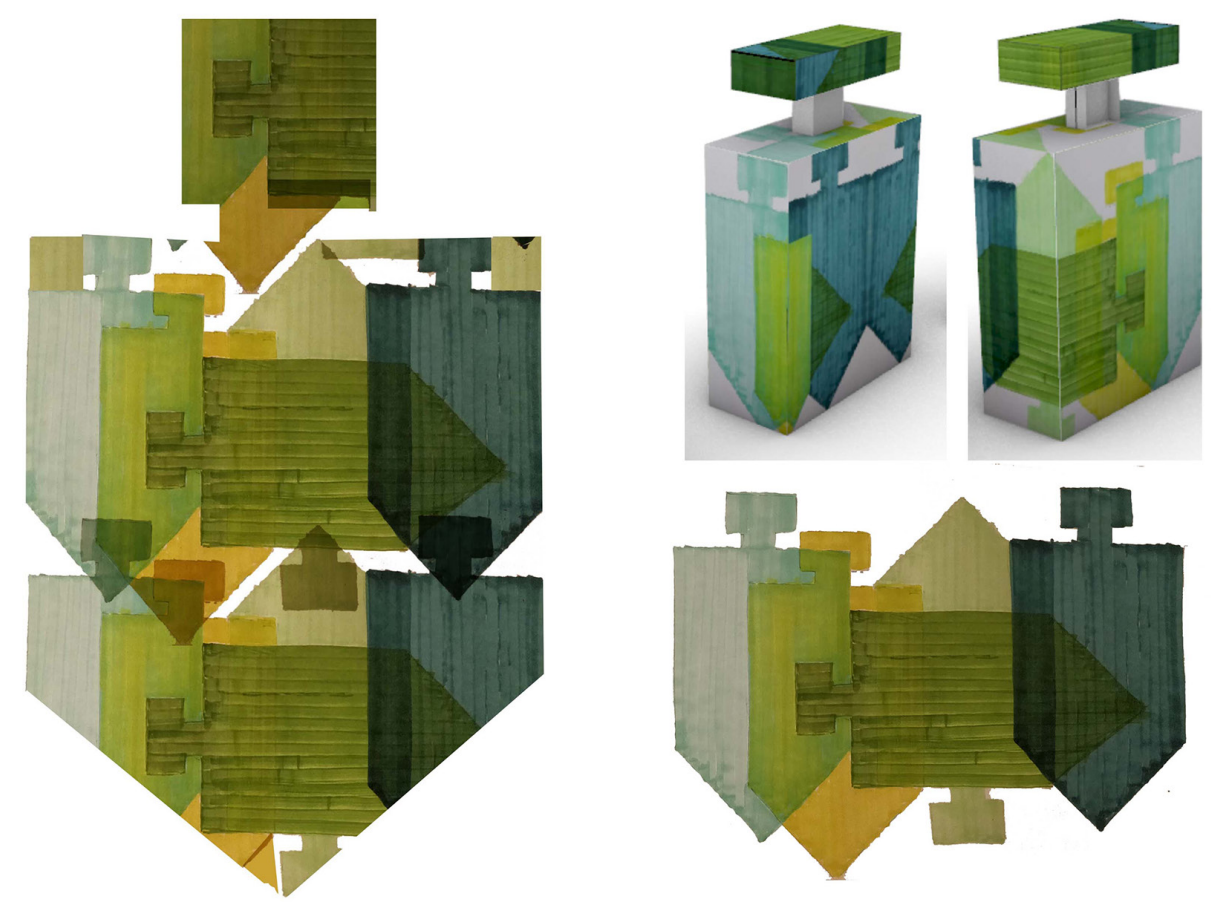

\section{Conclusioni}

Focus della presente ricerca è la forza del disegno. Disegno inteso come strumento di enorme valore capace di generare e ideare nuovi significati, assemblare e connettere forme esistenti, scomporre e frammentare anche le geometrie più complesse. II disegno quindi, in banco e nero, a colori o attraverso tecniche tradizionali e digitali costituisce uno strumento nelle mani del progettista che riesce a generare infinite ed inattese letture dell'oggetto analizzato (fig. I I ). L'idea originale che ha guidato l'intera sperimentazione è stata quella di creare texture non completamente libere ma derivate dall'oggetto analizzato, si è partiti quindi da un vincolo che è la riconoscibilità del soggetto studiato, dimostrando quanto le soluzioni grafiche risultino illimitate. I risultati raggiunti riguardano quindi la progettazione, attraverso l'utilizzo di tecniche integrate, di texture personalizzate capaci di arricchire "la pelle" di qualunque oggetto di uso comune. Essenziale infatti è sottolineare che la presente ricerca si pone non come sperimentazione relativa soltanto ad un caso studio specifico ma come metodo di applicazione generale. Obiettivo futuro è quello di procedere con tali sperimentazioni che potranno essere applicate anche ad oggetti di diversa natura o packaging di uso comune. Obiettivo ultimo della ricerca è quindi quello di conferire valore a qualunque oggetto, anche il più semplice, attraverso l'utilizzo dei preziosi strumenti del disegno e della creatività. 


\section{Note}

[I] Si veda: <https://www.sagrafica.it/pattern-e-texture-cosa-sono-e-quali-sono-le-differenze/>.

[2] Si veda: < http://www.treccani.it/vocabolario/texture/>.

[3] Si veda: < https://www.settemuse.it/arte/corrente_neoplasticismo_de_stijl.htm>.

[4] Si veda: < https://www.artonweb.it/artemoderna/astrattismo/articolo3.htm>.

\section{Riferimenti bibliografici}

Albisinni Piero, Chiavoni Emanuela, De Carlo Laura (2010). Verso un disegno integrato. La tradizione del disegno nellimmagine digitale. Roma: Gangemi Editore.

Fiell Charlotte, Fiell Peter (2005). Design del XX secolo. Colonia: Taschen.

Greenberg Clement (2004). I Classici dell'Arte. II Novecento. Klee. Milano: Rizzoli Skira.

Itten Johannes (1992). Arte del colore: esperienza soggettiva e conoscenza oggettiva come vie per l'arte. Milano: II Saggiatore Editore.

Migliari Riccardo (2004). Disegno come Modello. Roma: Edizioni Kappa.

Morlacchi Marcella (2008). Il libro del Disegno. Roma: Gangemi Editore.

Pettoello Giulia (20।4). From Real to Paper: Layers On-Off. In Emanuela Chiavoni, Piero Albisinni. Experiences and Reflections on Architectural Design. Roma: Aracne Editore, pp. 99- 104.

Will Jones (20I I). Architects' Sketchbooks. Milano: L'Ippocampo.

\section{Autore}

Giulia Pettoello, Sapienza Università di Roma, giulia.pettoello@uniromal .it

Per citare questo capitolo: Pettoello Giulia (2020). Disegno e geometria: un itinerario creativo per la progettazione di textures e patterns/Drawing and geometry: a creative itinerary for designing textures and patterns. In Arena A., Arena M., Brandolino R.G., Colistra D., Ginex G., Mediati D. Nucifora S., Raffa P. (a cura di). Connettere. Un disegno per annodare e tessere. Atti del $42^{\circ}$ Convegno Internazionale dei Docenti delle Discipline della Rappresentazione/Connecting. Drawing for weaving relationships. Proceedings of the 42th International Conference of Representation Disciplines Teachers. Milano: FrancoAngeli, pp. 1310-1329. 


\title{
Drawing and Geometry: a Creative Itinerary for Designing Textures and Patterns
}

\author{
Giulia Pettoello
}

Abstract

The focus of the present research is the transformation of the form. Multiple graphical modes are studied and used to weave, transform, and modify the lines of a drawing, starting with a recognition of the geometric shapes that underlines a particular object. These objects are not necessarily designer objects, but rather - even mostly- objects of everyday use. The central arguments are therefore drawing, geometry, communication, and multimedia. The goal is to represent and communicate objects through integrated graphical techniques, both traditional and digital. In particular, the theme of creative design is addressed starting with the geometric figures identified in the shape of the object, texture, and patterns. Drawing is therefore intended as a tool to trace and weave forms and geometries, thus new, still unexpressed meanings. Going further, it is intended as a tool to connect and generate multiple, original interpretations of reality at a historical time when the exterior aspect, and therefore the object's capacity for communication, has a large influence on a product's success on the commercial level. To be effective, the 'skin' of the object and therefore its texture should both respond to an elevated level of graphical quality, but also and especially be based on an idea of a meaningful project. Drawing is the main tool capable of managing each phase of the creative process, from initial ideation to the chromatic representation of the final product. Drawing is therefore intended as a tool for analysis, reading, study, and creative sources.

Keywords

design, geometry, creativity, texture, 3D modeling.

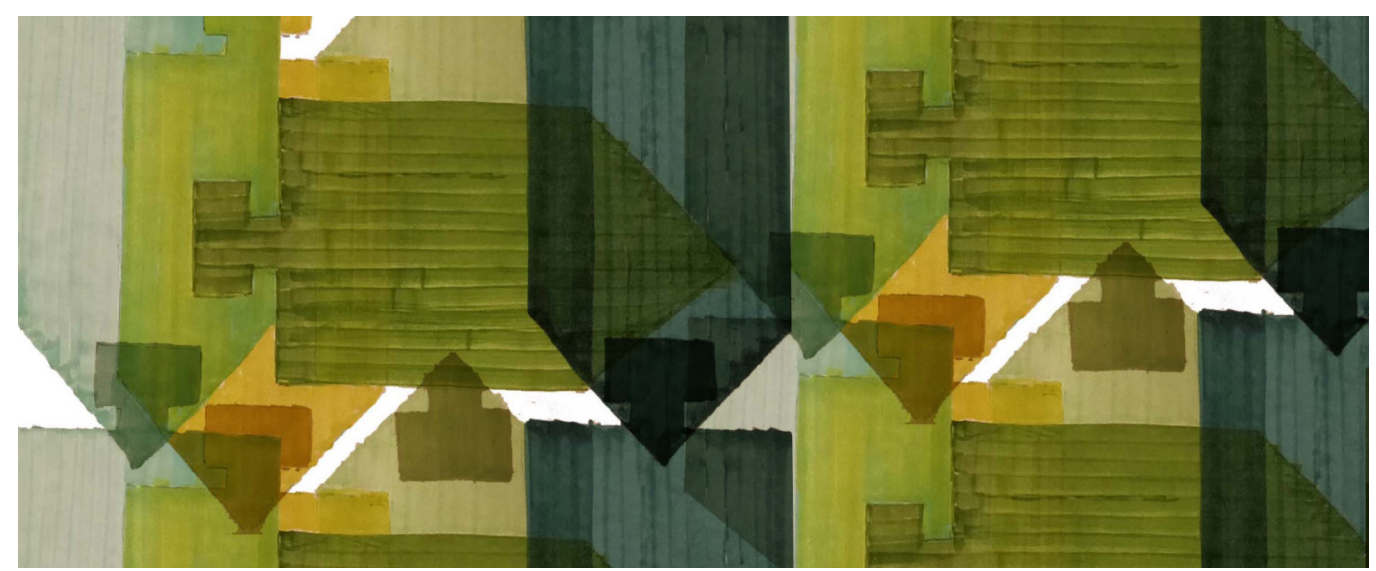




\section{Introduction}

"Texture is defined as the visible and tactile quality of the surface of an object, whether it is smooth, rough, soft, or hard; it is essentially a visual effect that adds richness and dimension to a composition. The term texture derives from the Latin textura, meaning web or weaving. A pattern, instead, is an image formed from the combination of organic or geometric shapes and is technically a motif or design that is repeated according to a symmetry and order. Patterns may be simple or complex, but in contrast to textures, they appear to be much more structured" [I].

The present research, which is an ongoing work, entails the creation of so called 'reasoned' textures, starting with an in-depth study of different types of everyday objects which are to be texturized. In particular, the case studies presented here as examples regard commercial perfume bottles with various forms, from the most simple to the most complex (fig. I). The texture and decorative motifs in general are not dictated by the instance, but derive from a creative process resulting from graphical analysis of the main geometries identified in the object and their decomposition. The 'skin' of the object therefore does not constitute mere aesthetic value; it also holds communicational value. The object is therefore the designer's main source of inspiration.

Different phases of reading, decomposition, and reassembly follow each other to design the final texture. As very meaningully expressed by Poincaré, "Creativity means combining pre-existing elements with new connections" [Poincaré, 1929]. Throughout the course of the present work, representation implies the creative operation that 'dismantles' and 'reassembles' the object on the paper, causing new characteristics, new meanings, and therefore new ideas to emerge (fig. 2).

Fig. I. Scomposition and reconstruction of the object: the glass, free hand sketches (grap
elaboration by the author).
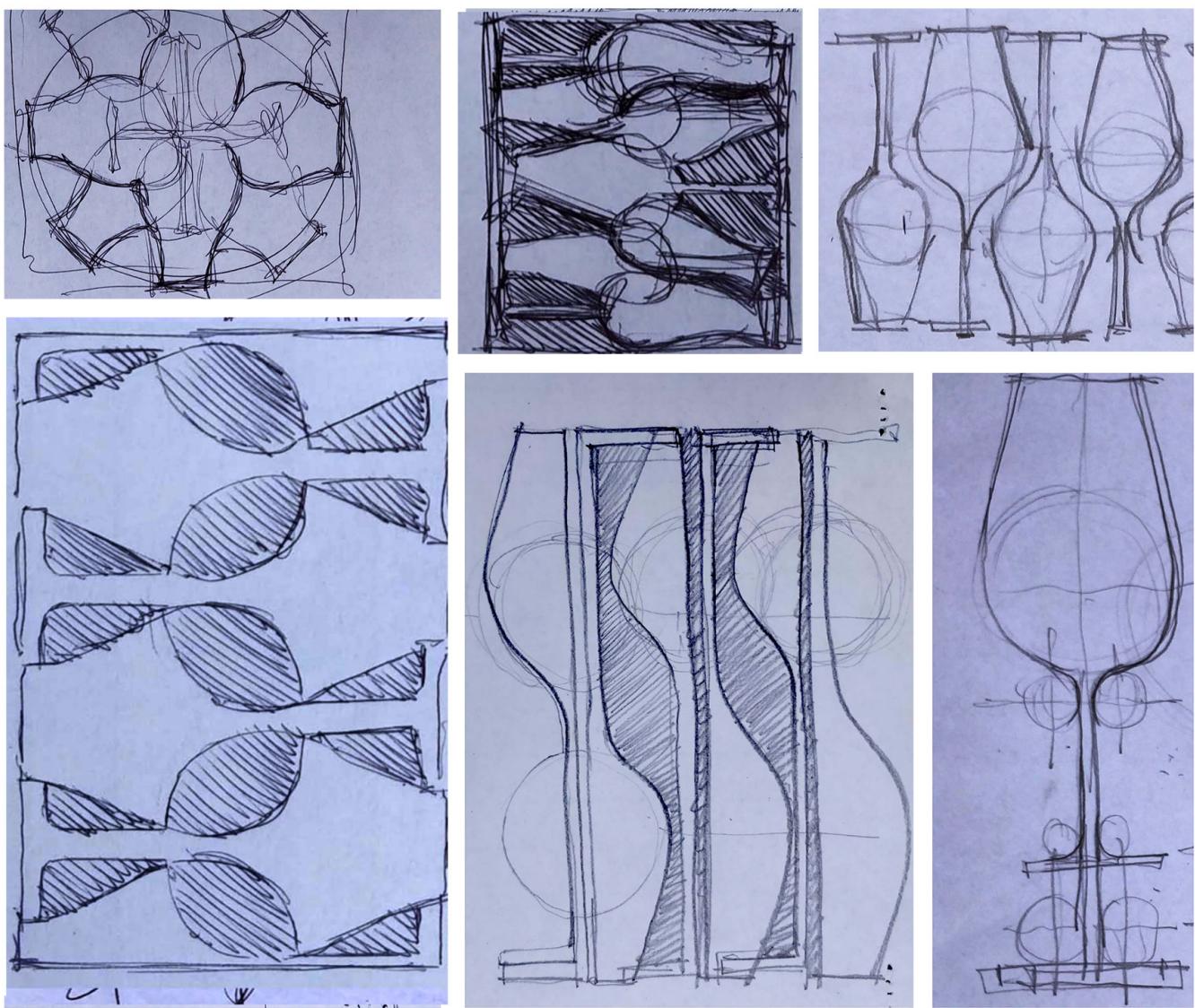
Drawing plays a fundamental role in different phases of the process. It is initially a tool to understand, analyse, and study the object; later in the creative and design phase, it is essential for analysing and comparing different hypotheses. Finally, drawings are the means through which ideas take shape (fig. 3).

The source of inspiration and basis of comparison over the course of the present research was the work of Bruno Munari. "Considered one of the greatest participants in twentieth-century art, design, and graphics, [he] maintained his brilliant creativity in support of constructive investigation of the form through visual and tactile experimentation, as well as his great capacity for communication using words, objects, and toys. Originally close to futurism, he then moved away, gradually dedicating his research to the investigation of forms and colours and the aesthetic autonomy of objects" [2].

\section{References and state of the art}

The research begins by interpreting the De Stijl movement, moving on to create a reading and personal application of the aspects analysed. "Nieuwe Beeldende, or Neoplasticism, also known as De Stijl (which is Dutch for The Style) is an artistic movement founded in the Netherlands in 1917. The term neoplasticism appeared for the first time in October 1917 with the publication of the first issue of the journal De Stijl founded by Theo Van Doesburg. The term was used by Piet Mondrian and Theo van Doesburg when drafting the De Stijl Manifesto to describe the new art form: abstract, essential, and geometric" [3].

The research begins with De Stijl criteria in fact it begins from a basic geometrical matrix. However, the experimentation evolves into production where ample room is given to imagination and where the rules underlying the different compositions vary constantly, even giving rise to very nonuniform graphical results. "De Stijl gathers the legacy of many

Fig. 2. Scomposition and reconstruction of the object: perfume bottle, free hand sketches (graphic elaboration by the author).

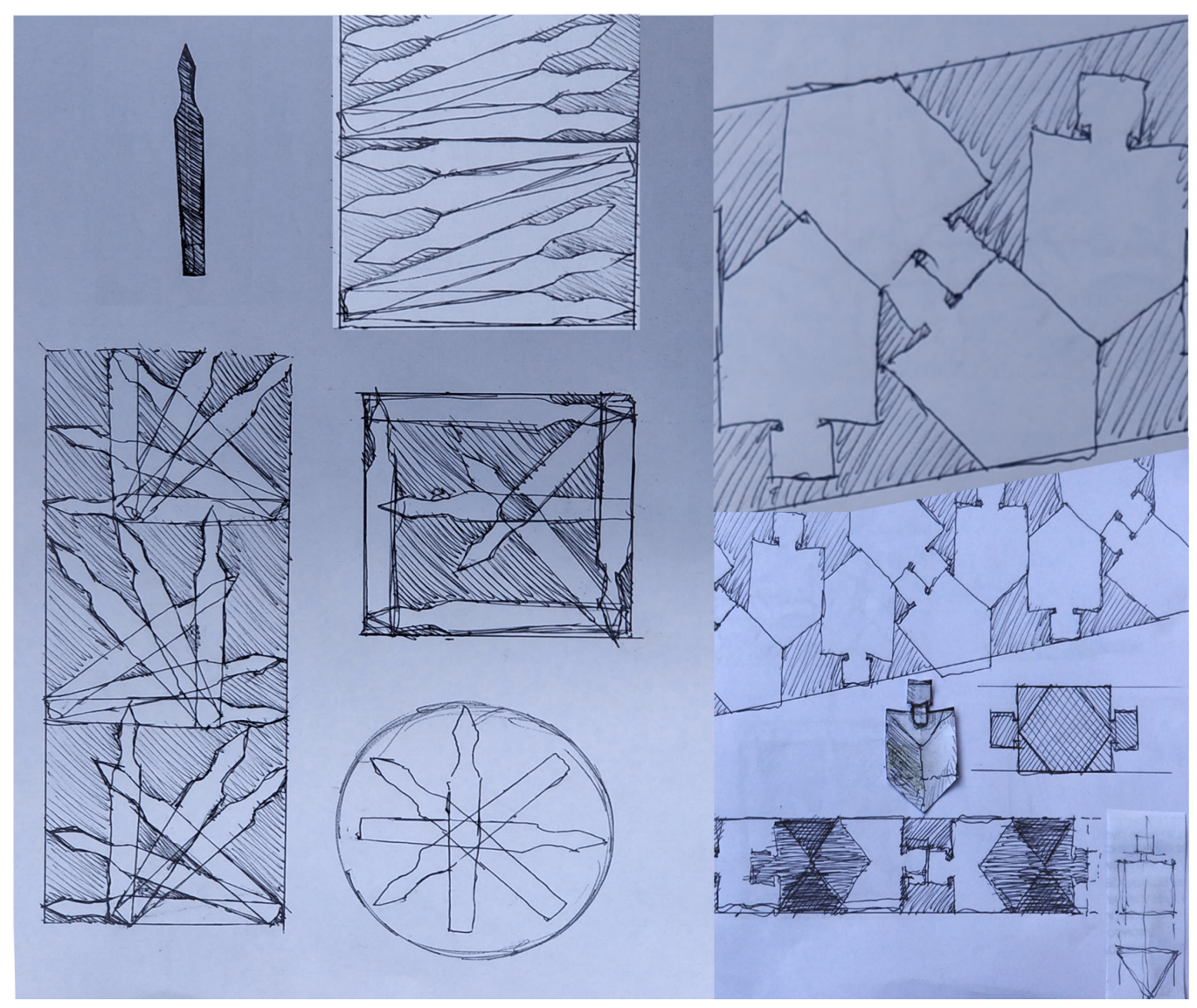


Fig. 3. Sketches of analysis day use (graphic elaboration by the author).

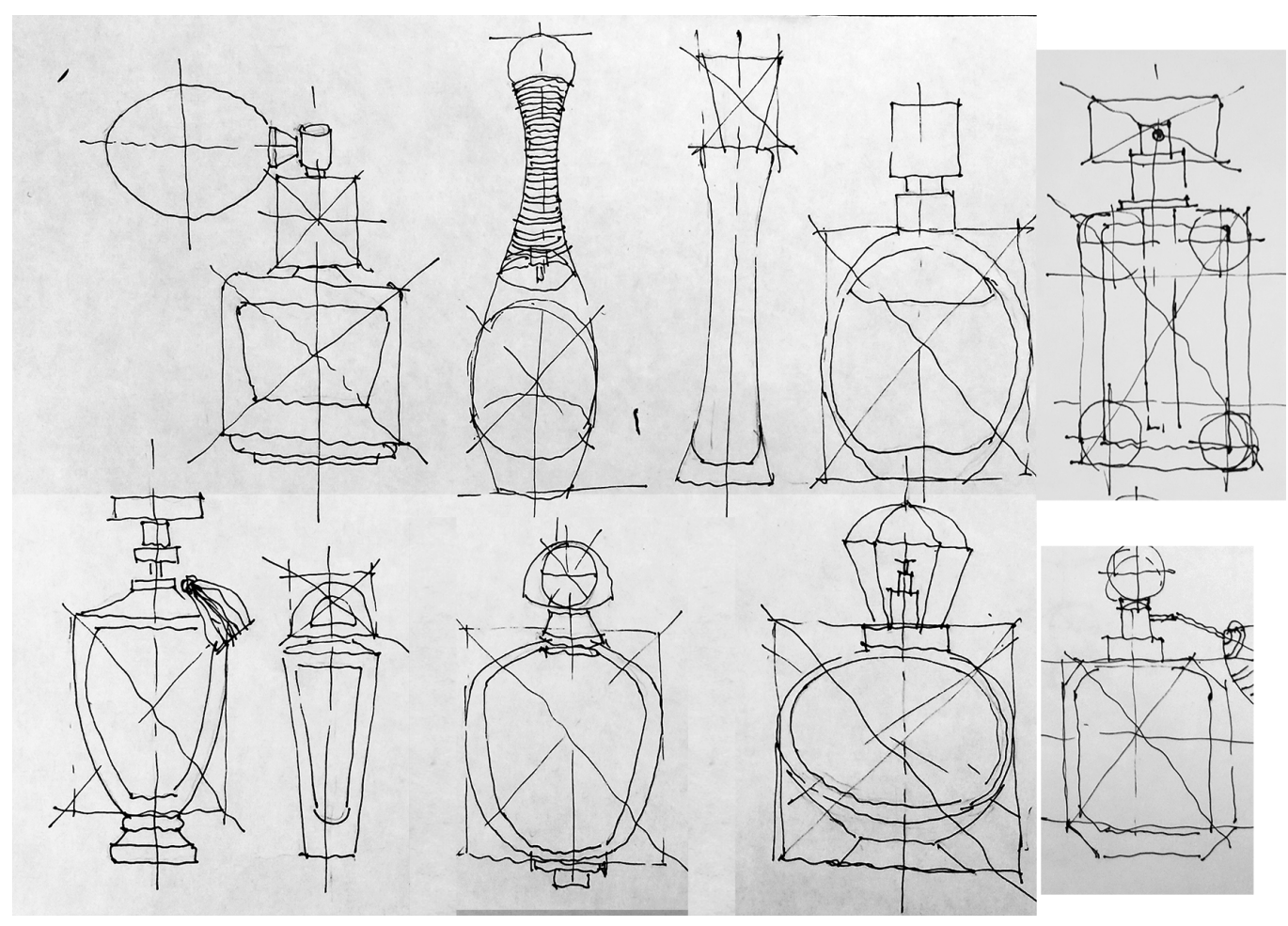

Fig. 4. Study drawings: positive-negative representation. Traditiona and digital technique

(graphic elaboration by the author).
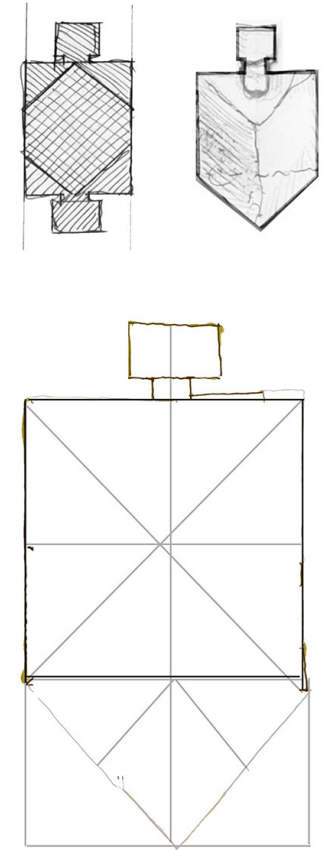
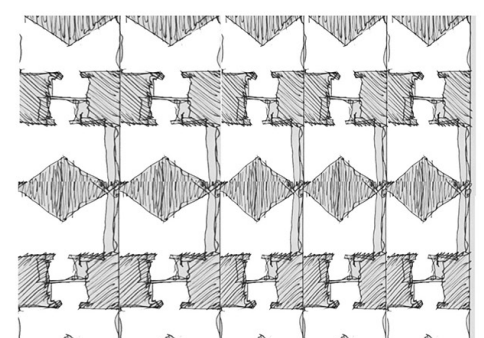
I
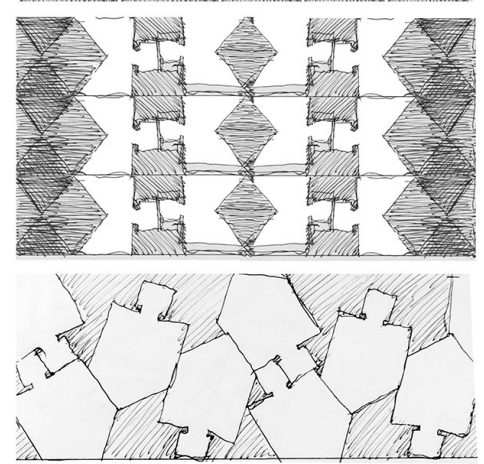
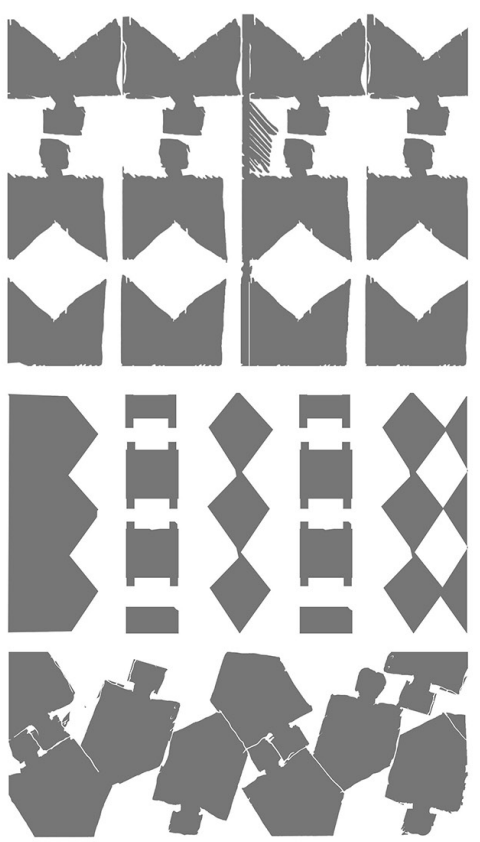
avant-garde movements, taking to the extreme the consequences of the search for the geometric essence of the form introduced by Cezanne. His elimination of the vanishing point gave rise to the Cubists, the decomposition of the complex form into elemental parts initiated by analytical Cubism, and the expressive autonomy of Fauvist colour matrix, inevitably reaching the elimination of any realistic or figurative content, replacing it with purely self-referential forms" [4]. In particular, the characteristics filtered and reinterpreted by De Stijl allowed an essential graphical synthesis to be achieved, rejecting the purely decorative element.

The present research therefore begins with these concepts, adapting them to everyday objects, giving them a different reading, and analysing the unlimited graphical potential that is still unexpressed. In particular, as well as De Stijl, the Cubist movement is also used as a reference. Between the various works considered here the principal ones are reported: La Chitarra (Pablo Picasso) and the papier collé, Violino e pipa (Georges Braques 19I3). In fact, in the present research, the objects studied are never considered only with respect to their main elevation but are rotated, decomposed, and reassembled to appropriate their essence and generate new graphical interpretations.

Studies of the work done by Ettore Sottsass (19/7-2007) was also essential. This architect and designer never stopped with a single meaning of the form, but always looked for new interpretations. Particularly meaningul are his experiments with glass and crystal made for the glassworks Vistosi, but also the works that grew out of the creativity of Memphis (an Italian design and architecture collective founded by Sottsass that was active between $198 \mathrm{I}$ and 1987). Among all the works by this multifaceted artist, emphasis is placed on the Carlton bookcase, which became the symbolic element of the Memphis group's entire production.

In sum, therefore, the original contributions of the present research particularly regard the proposed method, which aims to create new graphical meanings in the objects analysed. This is not limited to just the decomposition of the object, but also includes its geometry, which becomes the source of inspiration for new forms of representation synthesized in textures and patterns.
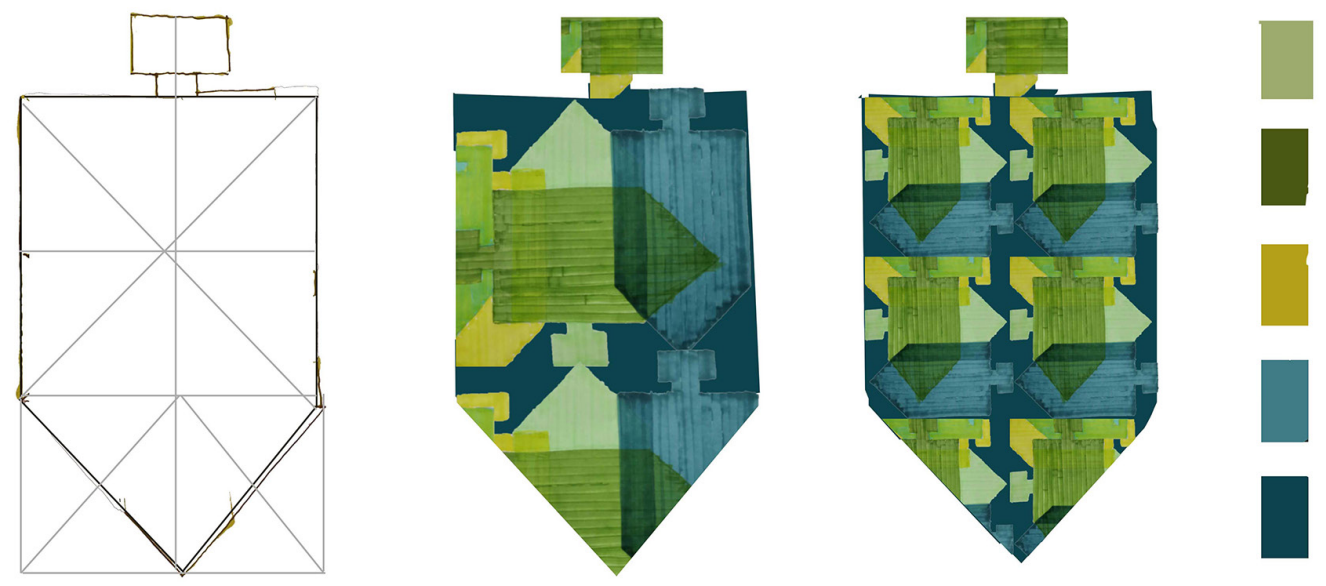

Fig. 5. Texture realization.
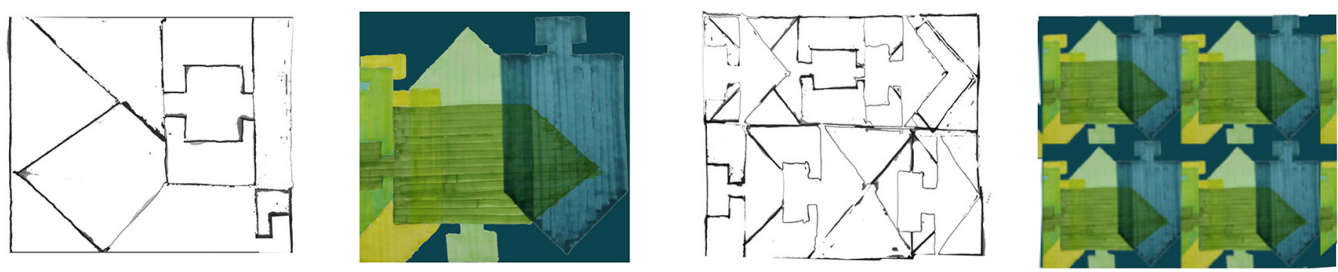


\section{Steps in the creative process}

The present study, which is work in progress, analyses existing everyday objects to build a design path capable of reinterpreting and rereading the same object in a different key. The object is initially studied through black-and-white freehand sketches; only later, after having revealed and carefully measured the metric and geometric characteristics, is the object represented using the rigorous methods of representation. After this initial critical approach to the object, a sort of 'creative decomposition' of the object is made, creating a synthetic outline of the object that maintains, as the only design restriction, the recognisability of the object under study. This outline, or cut-out, is used as the base module to generate textures and patterns deriving from the juxtaposition, superposition, and joining of the base silhouette (fig. 4). In particular, with regard to the more essentially geometric aspect, the most important of the main procedures tested are the following: reflection with respect

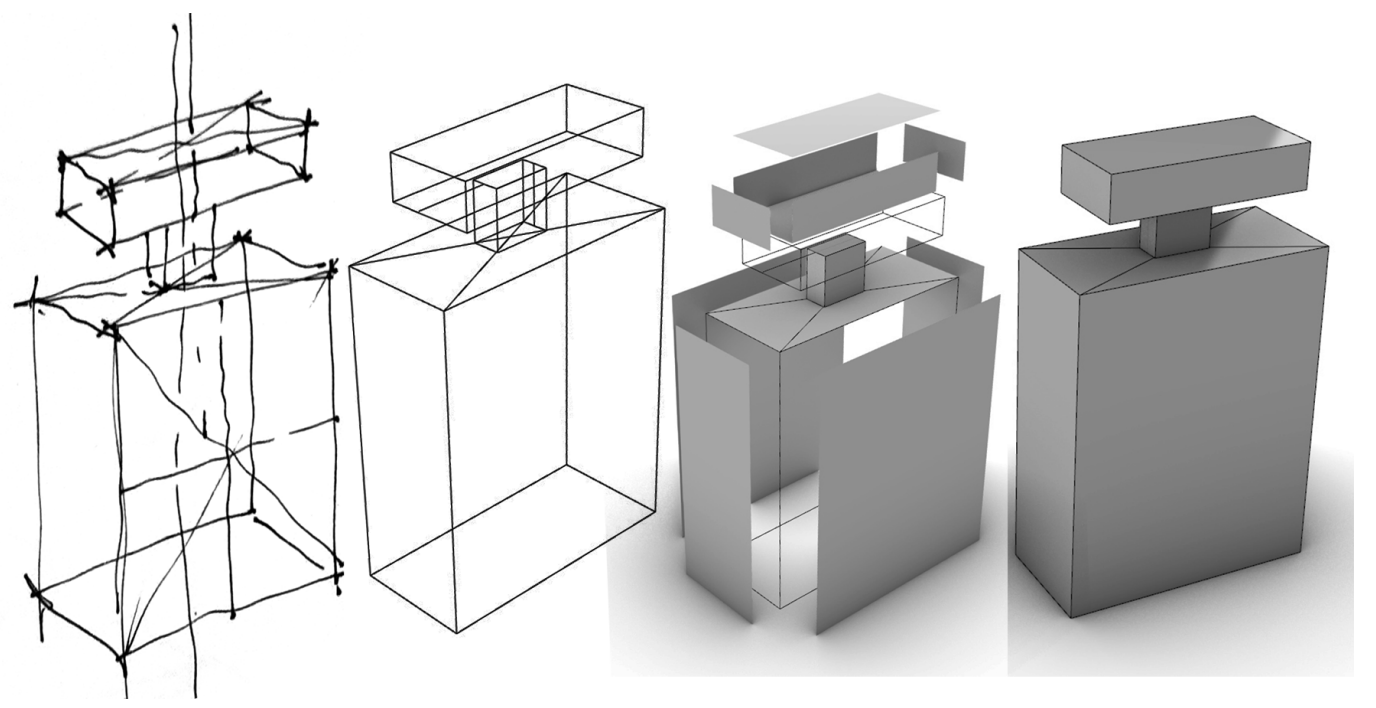

to a perpendicular axis of symmetry, or one that is inclined with respect to the basic plane of reference; rotations with respect to a central or shifted axis passing through a chosen point of the figure itself; and projections of the outline of the object displaced at random in space with respect to the $x, y, z$ axes. Finally, the introduction of colour occurs in a rather traditional way, using watercolour and Pantone techniques (fig. 5).

After this initial phase of study, which relied on essentially traditional techniques, a three-dimensional digital model of the object was created using the software Rhinoceros in which the previously created textures were then applied (fig. 6). As is known, the application of texture to the $3 \mathrm{D}$ model is carried out according to different modes that are more or less automated according to the characteristics of the basic texture. For repetitive elements, it is possible to 'unwrap' the object directly within the software and then proceed to develop the final object digitally (fig. 7). However, if the texture is characterized by a more complex design where it is possible to create continuity between the faces of the object, the surface must be 'developed' manually, followed by the application of the texture within the software (fig. 8).

The possibility of continuing to develop the product created with traditional techniques in the digital realm holds great value (fig. 9). For example, the multiplication of the basic motif previously created with traditional techniques is one very interesting aspect. Within the software Rhino, it was possible to establish the most suitable factor of repetition by acting on the UV mapping. Once the juxtaposition and connection between the faces 
were studied, it was enough to introduce a multiplicative factor to create textures with repeated designs, thereby creating 'mosaics' and very clear joints. This step is also interesting: where before it was the designer who dictated the rules via various graphical and chromatic experiments, now it is the software that, with respect to the material produced, develops and creates new possible output. This output is sometimes also unexpected because it is the result of a dynamic, flexible process between designer and computer-based tool (fig. I0).

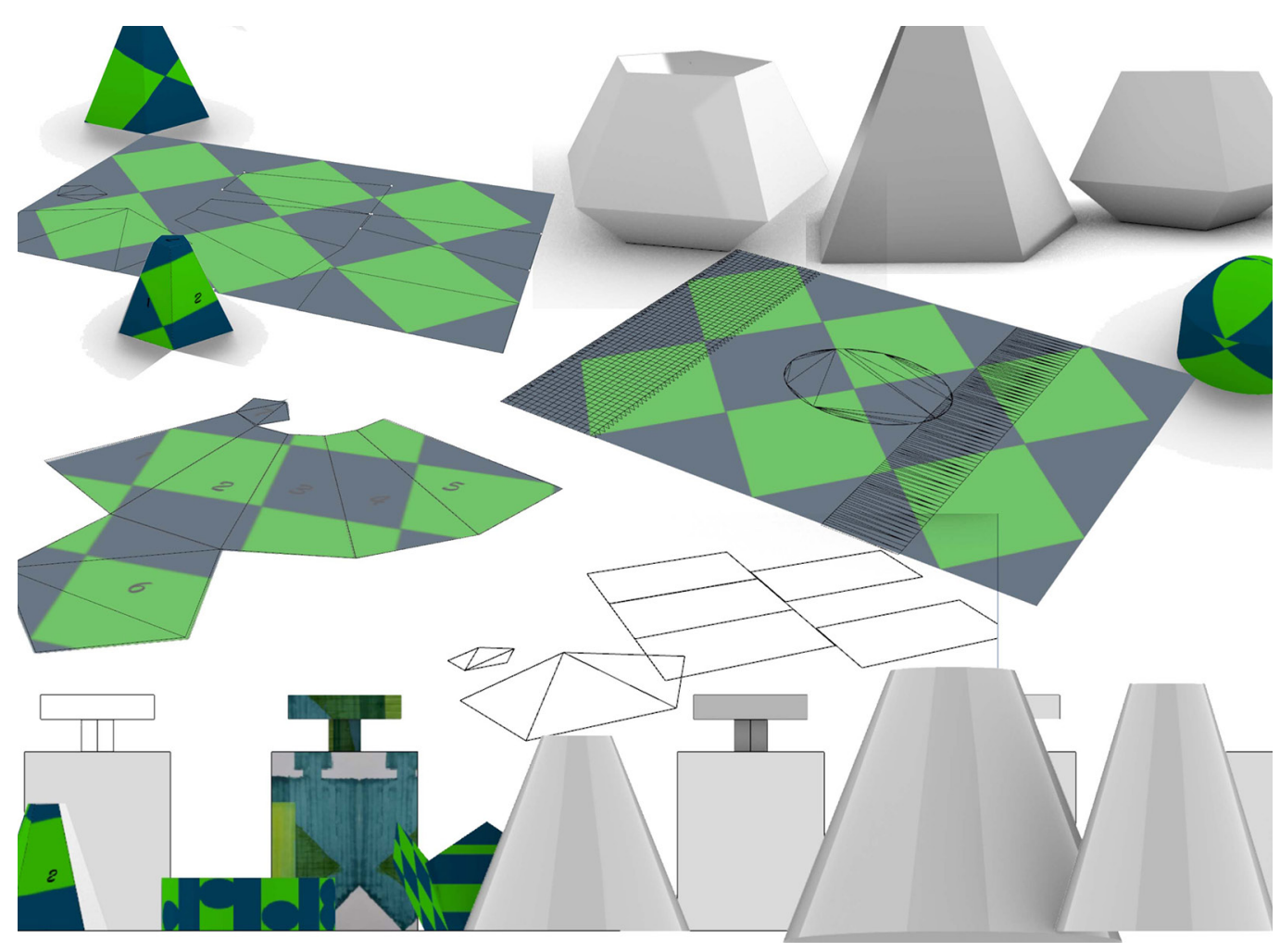

\section{Geometric structure}

As mentioned above, the texture's generating motifs are deduced from the careful analysis, understanding, and isolation of the main geometric figures that underlie, envelop, and characterize the object under study. The design or ideative flow, of the texture is therefore strongly influenced by the everyday object, which is in turn 'redressed' by this new characterization of the surface. The idea, therefore, lies in creating a virtuous cycle that, starting with a study of the object, through the decomposition and reassembly of its geometries, leads to a specific characterization of the object's surface, which is intimately connected with its form. The first operations of geometric decomposition naturally start with a graphical reading of the object, represented in dual orthographic projection. The second projection (elevations and sections) is primarily used to identify axes of symmetry and diagonal lines as well as other geometrically decisive elements such as lines of inflection or curved lines. Once these control elements have been determined, the true elementary geometric figures composing the object -or parts of them such as squares, rectangles, and circles- are identified. After extraction, the object's geometric figures determine the generating element, through which simple operations such as overturning, repetition, mirroring, reduction, and enlargement give life to the new texture. The texture may also naturally 

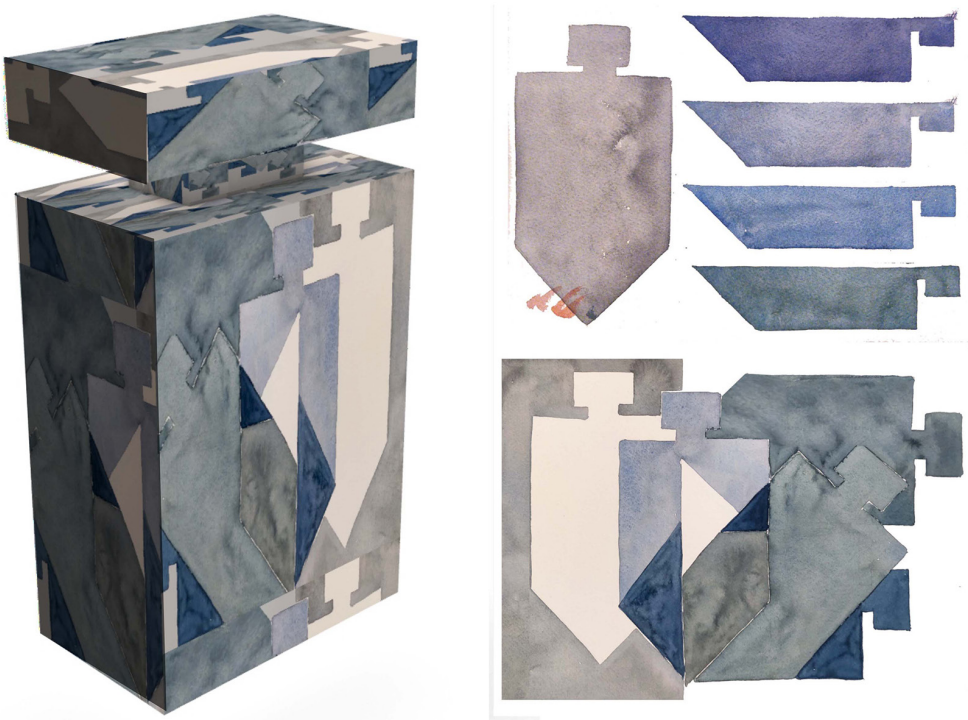

Fig. 9. Development of a surface and personalized exturing. Digital techni-
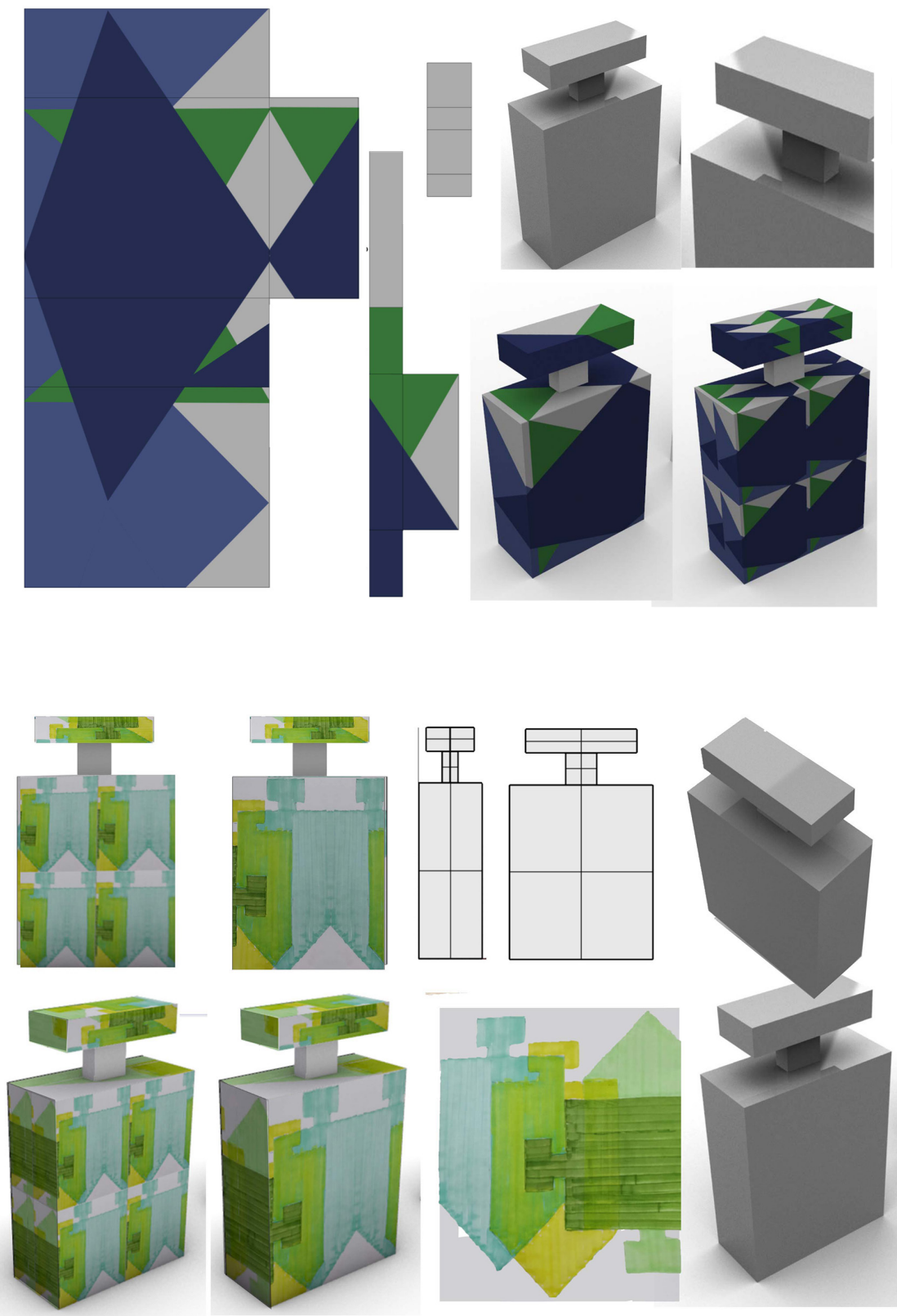
be generated by subtraction and addition of the various elements, as well as black/white contrast or rhythmic repetitions along a straight or curved path. The design process outlined thus is not confined to the interior of the elementary geometries extracted from the object. On the contrary, making use of this guiding idea, an infinite number of possible solutions are presented that vary based on the geometric element identified and the infinite number of possible combinations.

Fig. I I. Texture: contamination between traditional and digital technique (graphic elaboration by the author).
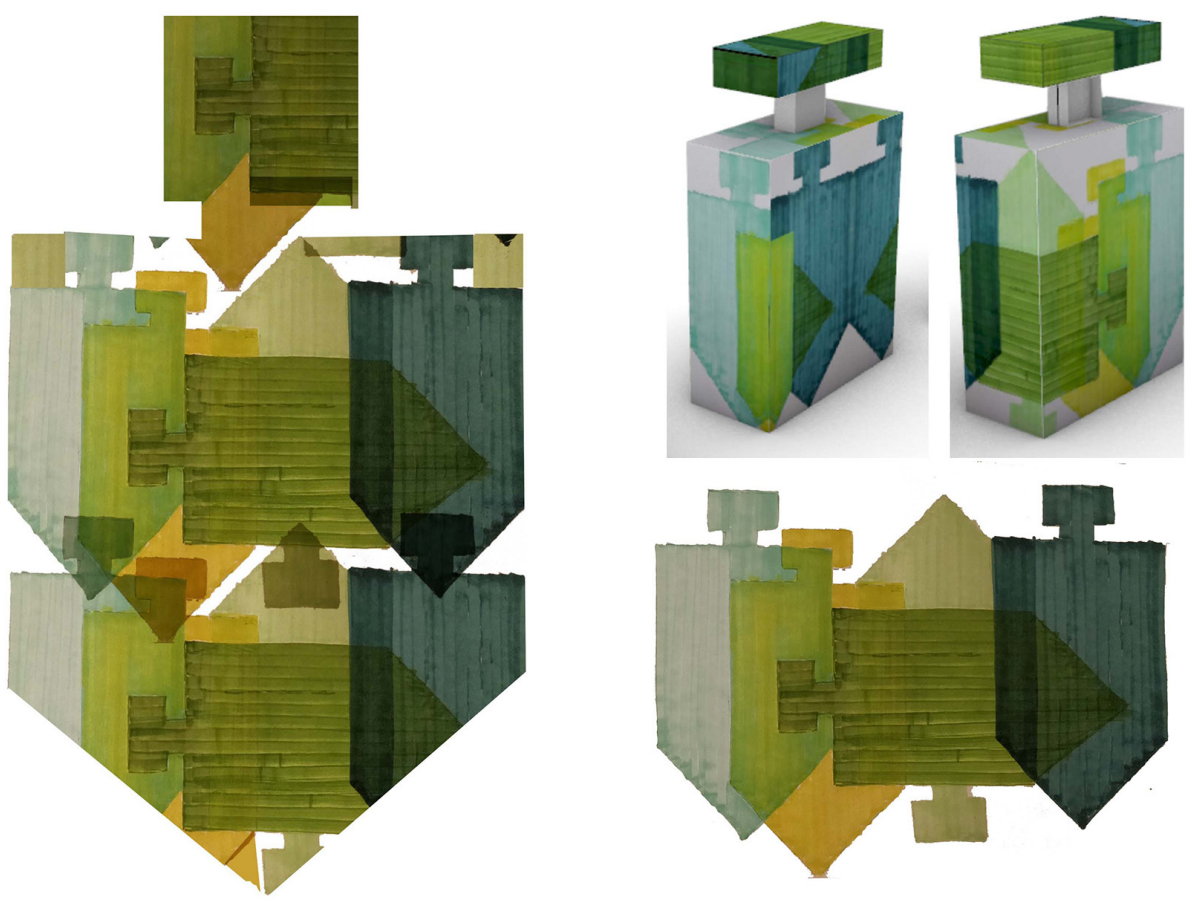

\section{Conclusion}

The focus of the present research is the strength of drawing, intended as a tool of enormous value capable of generating and ideating new meanings, assembling and connecting existing forms, decomposing and fragmenting even the most complex geometries. Therefore, whether black and white or colour, whether using traditional and/or digital techniques, drawings constitute a tool in the hands of the designer, who is then able to generate limitless unexpected readings of the object analysed (fig. I I). The original idea that guided this entire experimentation was to create textures that are not completely free, but which derive from the object analysed. The starting point was therefore the restriction that the recognisability of the subject under study, showing how the graphical solutions are unlimited. The results therefore regard the design, through the use of integrated techniques: traditional and digital, of customized textures capable of enriching 'the skin' of any common object. In fact, it should be underlined that the present research is not posed as experimentation related to one specific case study, but as a method for general application. A future objective is to proceed with this experimentation by applying it to different types of objects or common packaging. A future objective is to proceed with this experimentation, which will also be applied to different types of objects or low-cost packaging. The ultimate goal of the research is to confer value on any object, even the simplest ones, through the use of valuable tools for drawing and creativity. 


\section{Notes}

[I] Retrieved from: <https://www.sagrafica.it/pattern-e-texture-cosa-sono-e-quali-sono-le-differenze/>,

[2] Retrieved from: < http://www.treccani.it/vocabolario/texture/>

[3] Retrieved from: < https://www.settemuse.it/arte/corrente_neoplasticismo_de_stijl.htm>

[4] Retrieved from: < https://www.artonweb.it/artemoderna/astrattismo/articolo3.htm>.

\section{References}

Albisinni Piero, Chiavoni Emanuela, De Carlo Laura (20l0). Verso un disegno integrato. La tradizione del disegno nellimmagine digitale. Roma: Gangemi Editore.

Fiell Charlotte, Fiell Peter (2005). Design del XX secolo. Colonia: Taschen.

Greenberg Clement (2004). I Classici dell'Arte. II Novecento. Klee. Milano: Rizzoli Skira.

Itten Johannes (1992). Arte del colore: esperienza soggettiva e conoscenza oggettiva come vie per l'arte. Milano: II Saggiatore Editore.

Migliari Riccardo (2004). Disegno come Modello. Roma: Edizioni Kappa.

Morlacchi Marcella (2008). Il libro del Disegno. Roma: Gangemi Editore.

Pettoello Giulia (20।4). From Real to Paper: Layers On-Off. In Emanuela Chiavoni, Piero Albisinni. Experiences and Reflections on Architectural Design. Roma: Aracne Editore, pp. 99- 104.

Will Jones (201 I). Architects' Sketchbooks. Milano: L'lppocampo.

\section{Author}

Giulia Pettoello, Sapienza Università di Roma, giulia.pettoello@uniromal .it

To cite this chapter. Pettoello Giulia (2020). Disegno e geometria: un itinerario creativo per la progettazione di textures e patterns/Drawing and geometry: a creative itinerary for designing textures and patterns. In Arena A., Arena M., Brandolino R.G., Colistra D., Ginex G., Mediat D., Nucifora S., Raffa P. (a cura di). Connettere. Un disegno per annodare e tessere. Atti del $42^{\circ}$ Convegno Internazionale dei Docenti delle Discipline della Rappresentazione/Connecting. Drawing for weaving relationships. Proceedings of the 42th International Conference of Representation Disciplines Teachers. Milano: FrancoAngeli, pp. | 310-1329. 